\title{
ÇOCUK HAKLARINA DAİR SÖZLEŞME
}

\author{
Prof. Dr. Ali Naim INAN*
}

\section{GENEL OLARAK}

Uluslararası hukukta, dǐ̌ger bildiriler gibi, çocuk haklarına ilişkin, ister Milletler Cemiyeti (eski adıyla Cemiyet-i Akvam)'nin 29 Eylül 1924 tarihli Cenevre Cocuk Haklan Bildirisi, ister 20 Kasım 1959 tarihinde Birlesmis Milletler Genel Kurulunca kabul edilen Cocuk Hakları Bildirisi olsun, taraf devletlerin hükûmetleri tarafından kabul ve imza edilmesine rağmen hukuksal yaptırımı olmayan bazı genel ilkelerin ilân edilmesinden basska büyük bir anlam taşımamaktadırlar. Buna karşın, devletlerin iç hukuk (örneğin, Anay. mad. 90 ve 31.5.1963 t. ve 244 Nrl. Uluslararası Antlaşmanın Yapılması, Yürü̈rlüğü, Yayını ile Bazı Antlaşmaların Yapılması için Bakanlar Kuruluna Yetki Verilmesi Hk. K) kurallarına göre imza ve bilhassa bir kanunla da onaylandıktan sonra, taraf devletleri bağlayıcı niteliğe kavuştuğu ve dolayısıyla iç hukuk kurallarında, uluslararası andlaşma kuralları gereği yeni düzenlemeler veya değişiklikler yapma taahhüdleriyle taraf devletleri yükümlü kılar ve böylece uluslararası andlaşmalar da hukuksal yaptırma kavuşturulmuş olur.

Birleşmiş Milletler Insan Haklan Komisyonu, yukarıda açıklanan fikirler doğrultusunda Polanya Devletinin 1978'de yapığı önerisini dikkate alarak, yine Polanya tarafından hazırlanmış ilk taslağı derinlemesine incelemek üzere 1979 yılında, 43 üye devletin temsilcilerinin iştirakiyle çocuk hakları sözleşmesi konusunda bir "Çalışma Grubu" oluşturmuştur.

Bu çalışma grubu, İnsan Hakları Komisyonunun toplantısından evvel, her yilın ocak ayınin sonunda birer haftalık toplantılarda, (1979) Çocuk Hakları Yılının onuncu ve (1989) Birleşmiş Milletlerce Çocuk Haklan Bildirisinin kabulünün otuzuncu yıl dönümün-

\footnotetext{
* Emekli Örretim üyesi olup, halen Ankara, Anadolu ve Gazi Universitesi Hukuk Fakültelerinde COCUK HUKUKU dersini okutmaktadır.
} 
de "Çocuk Haklarına Dair Sözleşme (ÇHSöz.)" tasarısını hazırlamıştır'. Hazırlanan bu tasarının, Birleşmiş Milletler kurallarına göre, ilk önce (Şubat-Mart) 1989 da) tartışma ve onay için Insan Hakları Komisyonu'na, bilâhare (Mayıs-Haziran 1989 da) tartısıılmak ve nihaî oylamanın yapılması için Birleşmiş Milletler Genel Kurulu'na sevkedilmek üzere takvime bağlı bir program yapıldı².

Nihaî tasarı, 20 Kasım 1989 tarihinde Birleşmiş Milletler Genel Kurulunda oy birliği ile kabul edildi ve Birleşmiş Milletler Genel Kurulu temsilcilerince 26 Ocak 1990 tarihinde imza edildi. Sözleşme, 49 maddesinin I. fikrasına göre, 2 Eylül 1990 tarihinde yürürlüğe girdi ${ }^{3}$.

Türkiye, 1982 Anayasa'sının 3 ve 6. maddeleri ile 24 Temmuz 1923 t. Lozan Andlaşmasının hükümlerine aykırı gördüğü gerekçesiyle 17, 29, 30. maddelerine çekimce ${ }^{4}$ koyarak, Türkiye Cumhuriyeti adına zamanın Cumhurbaşkanı Turgut Özal tarafından 14 Eylül 1990 tarihinde Çocuk Haklanna Dair Sözleşme'yi imza etti. Sözleşme 1982 Aayasanin 90 . maddesine ve 31.5 .1963 t. ve 244 Nrlı K. hükümlerine göre, 17.29 ve 30 . maddelerine aynı gerekçelerle çekimce koyarak 9 Aralık 1994 t. ve 4058 Nrlı kanunla Çocuk Haklarına Dair Sözleşme (ÇHSöz.)yi onaylađı. Bakanlar Kurulı da sözleşmeyi 244 Nrlı K. 3. maddesinin 1. bendine göre 23.12.1994 t. ve 94/6423 sayılı karar ile yürürlü̆ğe koydu ${ }^{5}$.

\section{II. ÇOCUK HAKLARINA DAİR SÖZLEŞMENIN SISTEMI VE IÇERIĞí:}

Bir ÖNSÖZ, üç KISIM ve 54 maddeden oluşan Çocuk Hakla-

1. Bu calışmalann ayrıntıları için bkz.: DCI/UNICEF, mart 1988 t. ve 5 Nrlı. Dokümana tlişkin Bilgilendirme Seti s.1.

2. Bkz. DCI/UNICEF, Mart 1988 t. ve 3 Nrlt. Dokumana ilişkin Bijgilendirme Seti s.2.

3. Geniş bilgi için bkz. "Cocukların Yaşantılan, Korunmalan ve Geliştirilmelerine Illişkin Dünya Bildirgesi" ve Dünya Bildirgesinin Uygulanması için Faaliyet Raporu (Çocuklar lçin Dỉnya Zirvesi), B.M., New York, 30 Eylül 1990, s.9.

4. Türkiye, ÇH. Söz.nin bu maddelerine koyduğu çekimserlik. "Ihtirazî Kayıt" adı altında aynen şöyle ifade edilmiştir." Türkiye Cumhuriyeti Birleşmiş Milletler Çocuk Haklari Sözleşmesi'nin 17, 29 ve 30. maddeleri hükümlerini T.C. Anayasası ve 24 Temmuz 1923 tarihli Lozan Anlaşmas hükümlerine ve ruhuna uygun olarak yorumlama hakkını sakiı tutmaktadır. "Bu nedenle biz, aşağıdaki açıklamalarımızda bu ihtirazî kayıt ışı̆̆ altında 17, 29 ve 30. maddelerin bazı (ömeğin, ÇHSÖz. nin 17. mad c. bendinde yer alan "Çocuk kitaplarının üretilmesi ve yayılmastnın teşvikine" iliş̧kin) hükümlerinin Türkiye'de de uygulanabileceği kanaatını taşımaktayız. (RG. 27 Ocak 1995 t. ve sayı 22184 s.13.

5. R.G. 27 Ocak 1995 t. sayı 22184 s.1-33. 
nna Dair Sözleşme (ÇHSöz.)'de ilk önce bir ÖNSÖZ, eski deyimiyle bir dibace bulunmaktadır.

Sözleşme önsöz'ünde "insanlık ailesinin bütün üyelerinin dogustan insan haysiyetine sahip" olduklarını ve bunun yanında "eşitliğin ve (kişisel) hakların devredilmez nitelik taşıdığını; dünyada özgürlük, adalet ve başarmun temeli oldu ğu" vurgulanarak, insanlann temel hak ve özgïrlüklerinde daha iyi şartlar sağlamaya kararlı oldukların ve "ırk, renk, cinsiyet, dil ve din siyasal ya da başka görïs, ulusal ya da toplumsal köken, mülkiyet, doğustan veya baska durumlardan kaynaklanan ayrmctliklara" yer vermeyeceklerini, "uluslararast insan haklar evrensel bildirisinde, cocuklara özel bakum ve yardom hakki olduğunu ilân ettiklerini... ailenin toplumun temel birimi olduğunu" ve bu nedenle "çocuklar için doğal bir ortam" olduğu ve toplumda görev ve işlevini tam olarak yerine getirmesi için "gerekli koruma ve yardımı görmesinin zorunluluğuna inanmıs olarak" ve "çocuğun kişiliginin tam ve uyumlu olarak gelişmesi için mutluluk, sevgi ve anlayış" içinde "barıs, değerbilirlik, hoşgörü, özgürlük, eşitlik ve dayanısma ruhuyla yetistirilmesinin gerekliliğine" inanarak ve 1924 ve 1959 Cocuk Haklari Bildirileri ile Insan Haklan Evrensel Bildirisi'nin özellikle 23, 24, ve 10. maddeleriyle, Cocuğun Korunmasi ve Esenliğine İiskin Toplumsal ve Hukuksal hlkeler Bildirisi'ne ve bunun özel olarak yollamada bulunduğu 3 Aralık 1986 t. ve 41/85 sayılı Genel Kurul Kararıyla kabul edilen Ulusal ve Uluslararast Düzeyde Cocuklartn Evlat Edinme ve Koruyucu Yerlestirme, Cocuk Refahi ve Korumasi ile Ilgili Hukuksal ve Sosyal ilkelere Dair Bildiri, 29 Kasım 1985 t. ve 40/ 33 Genel Kurul Karariyla kabul edilen ve Beijing Kurallart olarak bilinen Cocuk Mahkemeleri Yönetimi Hk. Birlesmis Milletler Asgari Standartlar Kurallan ve 14 Aralı 1975 tarih ve 3318/XXIX sayılı Genel Kurul Kararıyla kabul edilen Silahlı Çatısma ve Olağan Ustï Durumlarda Kadin Ve Cocuklarn Korunmasi Hk. Bildirinin hükümlerini hatırlayarak "her ülkede, özellikle gelismekte olan ülkelerde, çocuğun yaşam kosullarnm iyileştirilmesi için uluslararast işbirliğinin önemini kabul" eden taraflar Çocuk Haklarına Dair Sözleşme'nin kuralları üzerinde anlaşmış olduklarını beyan etmişlerdir.

Önsözü takip eden 54 maddeden oluşan Çocuk Haklarına Dair Sözleşme Kuralları üç kısıma ayrılarak düzenlenmiştir.

Birinci Kusım

Birinci kısım, Insan Hakları Evrensel Bildirisinde olduğu gibi 
başłıca dört hak grubu içinde ${ }^{6}$ çocuk haklarma ilişkin kuralları içermektedir.

\section{Birinci Grup Haklar (Geniş Anlamda) MEDENI HAKLAR}

Bu gruptaki haklann bir kısmı özel hukuk alanına giren başka bir ifade ile medenî hakların kişi varlığına ve mal varlığına iliş̧in haklar olmakla beraber, bir kısmı da kamu hukuk alanına giren ve kişisel veya koruyucu haklar grubuna giren haklardan oluşmaktadır. Bu bakımdan geniş anlamda medenî hakları, dar anlamda "Medeni haklar" ve "kişisel (veya koruyucu) haklar" biçimde ikili bir ayrim altunda incelemek yerinde olur.

\section{a) (Dar anlamda) Medenî Haklar}

Çocuk Haklarına Dair Sözleşme'nin 1. mad. çocuğun tanımı; 7. mad. I. fik. isim ve tabiyet hakkı; ana-babasının kim olduğunu bilme hakkı ve onlar tarafindan bakılmasın isteme hakkı; 6 . mad. yaşama hakkı; 8. mad. kimliğinin korunması hakkı; 9. mad. temyiz yolu açık olmak üzere, çocuğun yararı dolayısıyla aynılmasına karar verilmedikçe, ana-babasından ayrılmamasını isteme hakkı; 9. mad. II. fik. da ana-babası tarafından kötü muameleye maruz bırakılması, ihmâl edilmesi; ana-babanın biribirinden ayrı yaşaması hallerinde, çocuğu koruyacak işlemler yapılırken (ilgililerin ve) çocuğun katılma ve görü̧slerini bildirme olasılığının tanınması; 9 . mad. III. fik. da, ana-babasindan veya bunlardan birinden ayrilan çocuğa, ana veya babasıyla düzenli bir biçimde kişisel iliş̧iler kurabilme ve doğrudan görüşme yapabilme hakkı; 15 . mad. (15/II. fık. kısıtlamalar saklı olarak) dernek kurma hakkı; çocuğun yüksek yararına uygun olarak yetiştirilmesi; geliştirilmesi sorumluluğunun ilk önce ana-babaya (gerekiyorsa vasiye veya diğer kişilere) ait ol-

6. İnsan Haklanı Evrensel Bildirisinde, ayrıca "Siyasî haklar" ayırım da yer almaktadır. Hukuk alanları bakımundan haklar, özel (medenî) hukuk hakları ve kamu hukuku haklan olarak ikili bit ayrım içinde incelenir. Kamu hukuku haklan da kişi dokunulmazlığı, özel hayatın korunması, yerteşme ve seyyahat özgürlìğỉ, düşüunce ve inanç özgiłrlügü gibi kişisel hak ve özgürlüklerden oluşan "kişisel veya koruyucu haklar" (Anay. m. 67 ved.) ve ailenin korunması, çalışma ve sözleşme özgürlüğü, sosyal güvenlik hakları, sağlık hakkı, öğretim hakkı gibi sosyal ve ekonomik hak ödevleri içine alan "Sosyal ve ekonomik haklar" (Anay. m.41 ved.) ile kişilerin siyasi etkenliklere katılmalarını sağlayan, vatandaşlık, seçme ve seçilme hakkı, dilekçe hakkı; kamu hizmetlerine karılma gibi sjyasi hak ve ödevlerinden oluşan "siyasî haklar veya siyast etkenliklere katılma haklart" (Anay. m.66 ved.) olarak ił̧̣ gruba ayrilarak inceleme konusu yapılır. Çocukların da birey, hukuksal deyimiyle gerçek kişi olmaları nedeniyle kamu hukuku haklarının bir çoklarından yararlanma imkanına sahip olmalan gibi, yaşlannın küçtiklüğł nedeniyle seçme ve seçilme haklarından tamamen, kamu hizmetlerine katılma haklarından kısmen yararlanmamaları da dogaldır. 
ması (mad. 18/, 27/II) bu sorumluluklannı yerine getirmekten yoksun olan ana-babaya durumlarina uygun devlet yardımının yapilmasını istemek hakkı (mad. 18/II, 27/II); 20/III. mad. koruyucu aile yanına yerleştirilmesini ve $21 /$. mad. evlat edinilme hakkı gibi haklar, medenî haklar ${ }^{7}$ grubuna örnek gösterilebilir ki bunlar (büyük bir kısmı bakımından) kişi olarak ele alınan çocuğun özel hukuk kurallanyla güvence altına alınması gereken haklarıdır.

\section{b) Kişisel (koruyucu) Haklar:}

Çocuk Haklarına Dair Sözleşme'de yer alan (geniş anlamda) medenî hakların diğer bir kısmı da çocuklara, kişi olması dolayısıyla veya doğrudan doğruya anayasa ve diğer kamu hukuk kurallariyla sağlanan koruyucu nitelik taşıyan kişilik haklaridır.

ÇH. Söz.'de ırk, renk, cinsiyet, dil, siyasal ya da başka düşünce, ulusal etnik ve sosyal köken, mülkiyet, sakatlık, doğuş ve diğer özellikleri nedeniyle ayncalık yapılmamasını, eşit davranılmasını istemek hakkı (mad.2/I) ve bu özelliklerinin korunmasını istemek hakkı (mad. 2/II); temel yaşama hakkı (mad. 6/I); hayatta kalma ve gelişmesini talep hakkı (mad. 6/II); ana-babası ile ayrılık, çocuğun kendisinin veya ana-babasının veya her ikisinin tutuklanması, hapis-sürgün ve sınır dışı edilmesi veya (tutukluluk hali de dahil) ölüm meydana gelmişse, çocuğun esenliliğine zarar vermemek koşuluyla istek üzerine çocuğa, ana-babasına, aile bireylerine, söz konusu aile bireylerinin durumu ve bulunduğu yer hakkında bilgi isteme hakkı (mad. 9/IV); aynlmış ailelerin birleşmesi için talepte bulunma ve ailenin birleşmesi için başka ülkeye girme ve o illkeyi terk etmeyi istemek hakkı (mad. 10); yabancı devlette olan anababastyla, olağan üstü durumlar haricinde kişisel ilişkiler kurma ve doğrudan doğruya görüşme hakkı (mad. 10/II); yasa dışı yollarla ülke dışına çıkarilıp geri döndürülmemesi halleriyle mücadele edilmesi (Mad. 11/II); görüşlerini oluşturma yeteneğine sahip çocukların, kendilerini ilgilendiren her konuda görüşlerini ifade edebilme özgürlüğü (mad. 12/I); ulusal yasalarn kurallarına uygun olarak, çocuğu etkileyen herhangi adlî veya idarî bir kovuşturmada bizzat çocuğun veya temsilcisinin dinlenmesi frrsatının verilmesini (mad. 12/II); başkalarının haklanna ve itibanna saygılı olmak, millî güvenlik, kamu düzeni, kamu sağlığı ve ahlâka aykırı olmamak kaydryla, yazılı, sözlü, sanatsal biçimde veya kendisinin seçeceği baş-

7. Bu ve bundan sonra yer alacak haklar, yukarıda 6 nrlı dipnotundaki açıklama içinde değerlendirilmelidir. 
ka bir araçla düşüncelerini açıklama özgürlüğü (mad.13); (14/II maddesindeki) kısıtlamalar sakh kalmak koşuluyla, düşünce, vicdan ve din özgürlüğ̈̈ (mad. 14/I) ve ana-babanın, vasilerin çocuğun yetenekleriyle uyumlu bir biçimde bu özgürlüklerinin kullanılmasında çocuğa yardımcı olma hususunda hak ve ödevlerinin varlığı (mad. 14/II); (15. mad. II. fik. kısıtlamalar dışında) barış içinde toplanma özgürlüğü (mad. 15/I); özel yaşantısına, aile konut ve iletişimine keyfi veya haksız bir biçimde müdahale yapılmamasını istemek ve bu hususta yasal korunma talep etme hakkı (mad. 16/I ve II); çocuğun, ana-babasının veya yalnız onlardan biri tarafindan (veya vasi veya vasi gibi çocuğun bakımını üstlenen kişilerce) ırza geçme dahil, bedensel veya zihinsel salderı, şiddet veya suistimale, ihmal veya ihmalkâr muamelelerle her türlü istismar ve kötü muamelere karşı korunması için yasal idarî, toplumsal ve eğitsel önlemlerin alınması (mad. 19/1); çocuğun her türlü cinsel sömürüye ve cinsel suistimallere karsıı korunmasının sağlanması (mad. 34); ister tek başına, isterse ana-babası veya herhangi bir kişi ile birlikte olsun mülteci çocuklar için özel korumaların sağlanması ve iltica hakkı (mad. 22); kaçırılma, satılma ve fuhuşa zorlanmasının önlenmesini isteme hakkı (mad. 35) ve çocuğun esenliğine zarar verecek her türlï sömürüuye karşı korunması (mad. 36); çocuklar, işkence veya diğer zâlimce, insanlık dıß̧ı veya aşağılayıcı muamele ve cezalara tâbi tutulamaz; onsekiz yaşından küiçük çocuklar idam edilemez, şartlı salı verilme koşulu olmayan müebbet hapis cezalarına çarptırilamaz (mad. 37/a bendi), özgürlüklerinden yasadışı ya da keyfi bir biçimde yoksun bırakılamazlar (mad. $37 / \mathrm{b}$ bendi). Özgürlüklerinden yoksun bırakılan çocuk, kendi yüksek yararı aksini gerektirmedikçe, cezaların yetişkinlerden ayrı yerlerde çekerler ve olağanüstï durumlar dışında aileleriyle, yazışma ve görüşme haklarina sahip olurlar (mad. $37 / \mathrm{c}$ bendi). Silâhlı çatışmalarda ulusal ve uluslararası ve insanî kurallarda ön görülen önerileri özellikle dikkate (mad. 38/I) ve onbeş yaşından küçük çocukların silâhlı çatı̧malara doğrudan doğruya katılmamaları ve silâhlı çatışmalardan korunmaları için her türlü önlemler alınmalıdır (Mad. 38/II). Taraf devletler, onbeş yaşından küęük çocukların askere alınmayacaklannı ve onbeş ile onsekiz yaşı arasındaki çocuklardan öncelikle yaşca büyüklerden başlayarak askere alınmasının sağlanmasını taahhüd eder (mad. 38/III).

Yasalara aykırı davrandığı iddia edilen ve bu nedenle suçlanan (itham edilen) ya da yasayı ihlâl ettiği kabul edilen çocuk, başkalarunda insan haklarına ve temel özgürlüklerine saygınlık ve değer 
anlayışını geliştiren, yaş durumu gözetilerek toplumla yeniden bütünleşmesini ve uyumunu sağlayıci muameleye tâbi tutulacak ve kendisine temel güvencelerden başka, durumdan ana-babasının ve ilgili kişilerin haberdar edilmesi, adlî yardımdan yararlanma, kanun yollarına başvurulabilme, anlamadiğı dilde yargılanması halinde parasız tercüman tutulması, gibi diğer hak ve güvencelerden yararlanmak (mad. 40) gibi haklar, kişisel (veya koruyucu) hakların örneklerini oluşturmaktadır ${ }^{7}$.

\section{Iikinci Grup Haklar: EKONOMIK HAKLAR}

Çalışan ana-babanın, çocuk bakım hizmet ve tesislerinden yararlanma hakkı (mad. 18/III); çocuğun dinlenme ve boş zamanları değerlendirme hakkı (mad. 31/I); ekonomik sömürüye, her türlüi tehlikeli işten, eğitim ve sağlığına, bedensel, zihinsel, ruhsal ve toplumsal gelişmesine zarar verecek çalışmalara karşı korunma hakkı (mad. 32/I); işe kabul yaşının ve çalışma koşulların düzenlenmesi (Mad. 32/II fik. a-b bendi); ıslâh ve topluma kazandırma (mad. 39) gibi haklar ekonomik hakların örneklerini teşkil etmektedir.

\section{Üçücü Grup Haklar; SOSYAL HAKLAR}

Kamu ve özel kuruluşlardan, adlî ve idarî makamlardan çocuklarla ilgili hususlarda çocuğun yararının etkili biçimde korunmasını istemek (mad. 3/I); çocuğun esenliği için ana-babasının, vasisinin veya kendinden sorumlu kişilerin hak ve ödevleri gözönünde tutularak devletten bakım ve korunmasının sağlanmasında yasal ve idarî önlemlerin alınması (mad. 3/II); sözleşmede çocuklara tanınan hakların uygulanması amacıyla her türlü yasal, idarî önlemler alarak; ekonomik, sosyal, ....haklara ilişkin olan eldeki kaynaklann geniş tutulmasını ve gerekirse uluslararası işbirliği çerçevesinde önlemler alınması (mad. 4); ruhsal, ahlâksal esenliği ile bedensel, zihinsel sağlığının geliştirilmesi için ulusal ve uluslararası bilgi ve belgelerin edinilmesi (mad. 17) ${ }^{8}$ sağlanmalıdır; çocuğun yetiştirilmesi, geliştirilmesi sorumluluğunu taşıyan ana-babaya bu sorumluluğunu yerine getirirken, durumlarına uygun devlet yardımı yapılmalıdır (mad. 18/II, 27/III) ${ }^{9}$. Geçici ve sürekli olarak çevresinden yoksun kalan veya kendi yararına bu ortama bırakılması kabul edil-

8. ÇH. Söz. bu 17 maddesine Türkiye, 17. maddenin a bendinde çekince koyduğu 29. maddeye gönderne yaptığı ve özellikle 17 . maddenin b ve $d$ bendlerinin Anayasamizın 3. ve 6. maddeleriyle Lozan Antlasmasının hüküimlerine aykın olduğg nedeniyle çekimce koymuştur. Aynca dipnotu 4'dekj açıklamalara bkz.

9. Bu veya buna benzer bazı haklar, nitelikleri gereģi, kişilik (koruyucu) hakları veya dar anlamda medenî haklar içinde de incelenebilir. 
meyen her çocuğun, devletten özel koruma ve yardım istemesi hakkı (Mad. 20/I) ve bu ortamlar dışında bakıcı (Koruyucu) aile yanına yerleştirilmesi ve evlatlığa verilmesini istemek hakkı (mad. 20/II). Zihinsel, bedensel özürlü çocuklar güvence altına alınmalı ve özel bakımdan yararlandırılmalı ve gerekirse ana-babasına veya onlar gibi sorumlu kimselere durumlarına göre devlet yardımı yapılmaltdır (mad. 23). Çocuk, olabilecek en iyi sağlık düzenine kavuşturulmalı, ııbbî bakımı ve rehabilitasyonu sağlanmalı, bebek ve çocuk ölümlerini azaltıcı önlemler alınmalıdır (Mad. 24 ve 25). Çocuklar sosyal güvenceye kavuşturulmalıdır (mad. 26). Çocuklar uyuşturucu, psikotrop maddelere karşı korunmalıdır (mad. 33). Çocuklar, her türlü pornografik gösteri ve malzemelere, cinsel sömürüye ve cinsel suistimallere karşi korunmalıdır (mad. 34) gibi hususlar sosyal hakların ömeklerini oluşturmaktadır.

\section{Dördüncü Grup Haklar: KÜLTÜREL HAKLAR}

Devletler kültiürel haklara ilişkin olarak ellerindeki kaynakları olabildiğince geniş tutarlar ve gerekirse uluslararası işbirliği çerçevesinde gerekli önlemleri alırlar (mad. 4). Çocuğun yeteneklerinin geliştirilmesinde, rehberlik yapılmasında, yönlendirilmesinde anababanın veya vasi gibi kendisinden sorumlu olan kimselerin haklarına ve ödevlerine saygılı olmak (mad. 5), kimliğinin... aile bağlannın korunması ve bunlara saygı gösterilmesi ve bu konulara yasa đışı müdahalede bulunulmaması ve bunlardan yoksun bırakılmamaması (mad. 8) çocuk kitaplarının üretilmesi ile yayılması teşvik edilmeli (mad. $17 \mathrm{c}$ ) ve eğitim (mad. 28) ve ilk öğretimin zorunlu parasız olması $\left(28,29 / \mathrm{a}\right.$ a ve b) ${ }^{10}$ ve çocuğa sanatsal yaşama ve uygun eğlencelere katılma hakkının tanınması (mad. 31/II) gibi haklar bu grup haklann örneklerini oluşturmaktadır.

\section{Ikinci Kısım}

Çocuk Haklarına Dair Sözleşmenin ikịnci kısmında, 42. madde sözleşme kural ve ilkelerinin taraf devletlerce uygun ve etkin araçlarla yetişkinlere ve çocuklara yaygın biçimde tanıtılması ve ögretilmesi yükümlülüğü getirilirken, 43-45. maddeleri arasında da, taraf devletlerin sözleşme yükümlülük ve sorumluluklarının yerine getirilip getirilmediğinin, çocuk haklarının korunmasındaki ilerlemeleri incelemek ve takip etmek üzere bir "Cocuk Haklan Komite$s i$ " kurulmasınt, bu komiteye üye seçimi ve çalışma yer ve usullerine ilişkin düzenlemeler getirilmektedir.

10. Dipnotu 9'daki açıklamalara bakınız. 
Çocuk Hakları Komitesi, taraf devletlerin, sözleşmede kurallara bağlanmış hususlarda uzmanlıklarıyla tanınmı̧̧ ve yüksek ahlâk sahibi kişilerden gösterecekleri adaylar arasından taraf devletlerin $2 / 3$ yeter sayılı toplantılarında hazır olanların gizli ve salt çoğunluguyla seçtiği on üyeden oluşmaktadır (mad. 45). Seçilen üyelerin görev suiresi dört yıldır ${ }^{11}$. Üyeler, aday gösterildikleri takdirde tekrar seçilebilirler. Ancak, ilk seçimde beş üyenin görev süresi iki yıl sonra biter. Bunlar, ilk seçimden sonra yapılacak ilk toplantıda, kura çekilerek belirlenir. Komite, iç tüzügüunü (yönergesini) kendisi yapar. Komite, büro ve diğer memurlarını iki yıl için kendi seçer. Toplantılarını olağan olarak, Birleşmiş Milletler Teşkilatının merkezinde veya komitenin belirleyeceği uygun başka bir yerde yapar. Komite, her yıl olağan olarak toplanır. Komite üyelerinin ücretleri, Birleşmiş Milletler Genel Kurulunca onaylanmak koşuluyla Birleşmiş Milletler Teşkilatınca karşılanır.

Çocuk Haklarına Dair Sözleşmeṇin 44. maddenin I. fıkrasına göre, sözleşmenin yürürlüğe girdiği tarihten itibaren ilk önce iki yll içinde, bilahare beş yılda bir taraf devletler Birleşmiş Milletler Genel Sekreterliği aracilığıyla bir rapor göndermek zorundadırlar. Çocuk Haklari Komitesi de taraf devletlerden gelen raporları ve uygun gördiiğï ek bilgileri de içeren faaliyet raporunu (mad. 44/IV) iki yılda bir Ekonomik ve Sosyal Konsey aracılı̆̆ıyla Birleşmiş Milletler Genel Kuruluna sunar.

Çocuk Hakları Komitesi, çalışmalarında UNICEF gibi Birleşmiş Milletler Teşkilatının uzmanlaşmış başka kuruluşlarından, taraf devletler hakkında bilgiler alabileceği gibi, istenilen hususlarda bu uzman kuruluşlara temsil yetkisi vererek gerekli incelemeleri taraf devletlerde yaptırmak suretiyle yardım talep edebilir (ÇHSöz. m.45). Komịte, taraf devlet raporlarını, elde ettiği diğer inceleme sonuçlarını ve diğer bilgileri değerlendirerek taraf devletlere telkin ve genel nitelikte tavsiyelerde bulunur. Taraf devletlerin, sayet varsa, bu husustaki açıklamalan (yorumları) ile Komite, telkin ve genel nitelikteki tavsiyelerini Genel Kurula sunar.

\section{Üçüncü Kıstm}

Çocuk Haklarına Dair Sözleşme'nin üçüncü kısmı 46-54 maddeler içinde sözleşmenin taraf devlețerce imza edilmesine (m. ad.

11. Ancak ÇHSöz. m,43/IV göre, ilk seçim sözleşmenin yüirürlụ̈̆ge girdiği tarihi izleyen altı ay içinde yapilır. Sonraki seçimler iki yılda bir değişecek beş üye için yapılır. 
46), onaylanmasına (mad. 47) ${ }^{12}$, yürürlï̆ğe girmesine (mad. 49), sözleşmeye katılma usullerine (mad. 48), değişiklik önerilerinin değerlendirilmesi usullerine (mad. 50) ile çekimser kalma (İhtirazi kayit (=Reservation) koyma) koşul ve usullerine (mad. 51), taraf devletlerin sözleşmeyi yazılı olarak fesih haklarının usulleriyle bunun sonuçlarına (mad. 52), Birleşmiş Milletler Genel Sekreterliğinin ÇHSöz.nin tevdi makamı olduğuna (mad. 53) ve ingilizce, arapça, çince, ispanyolca, fransızca ve rusça olan metinlerin de aynı derecede geçerli olduğuna (mad. 54) ilişkin kurallardan oluşmaktadır.

\section{III. ÇOCUK HAKLARINA DAİR SÖZLEŞMENIN İÇ HUKUK BAKIMINDAN DEĞERLENDİRILIMESİ}

\section{A. Genel Olarak}

Çocuk Haklarına Dair Sözleşmenin iç hukuk bakımından değerlendirilmesinin yapılabilmesi için, herşeyden evvel genel olarak "iç hukuk kuralları" ile "uluslararası hukuk kuralları"nın, başka deyişle uluslararası andlaşmalar kurallarının iç hukuk kuralları karşısında uygulanmasının nasıl yapılacağının araştırılması gerekir.

Uluslararası andlaşma (hukuk) kurallarının iç hukuk kuralları karşısında uygulanması, uluslararası hukuk literatüründe çok tartışılan konulardan birini oluşturmaktadır. Uluslararası hukuk ile iç hukuk kurallanının ilişkisini ele alan fikirleri esas itibariyle iki grupta veya doğru deyimi ile iki model içinde incelemek yerinde olur ${ }^{13}$.

Birinci fikir taraftarları, ister devletin bireysel iradesi, ister birleşik irade, ister karşllık iradesi olsun, fikirlerini devletin iradesine dayandırarak, DUALIST (=ikkicilik) modeli oluşturup, uluslararası (andlaşmalar hukuku) ile iç hukuk biribirinden tamamen ayrı iki hukuk olarak kabul ederek, biri diğerinin altında veya üstünde yer almayan yani biribirine eşit iki hukuk düzenidir, biçiminde ifade ederlerken; buna karşın ikinci bir grup MONIST (=bircilik) model taraftarı olarak, uluslararsı hukuk (andlaşmalar hukuku), bağlayıcı norm hiyararşisi, sosyal dayanışma gibi bazı objektif ölçütlere bağ-

12. Subat 1994 tarihine kadar 162 üye imza etmiş veya onaylamıştır. Geniş bilgiler için $11 / 9$ doküman dosya $23 / 2$.

13. Bu hususta ayrintulı abilgiler için bkz. GÖNÖNÇ, Levent; Anayasa Hukukunda Yeni Eğilimler, Milletlerarası Anayasa Hukuku, Yaymlanmamış Yłaksek Lisans Tezi, Ankara 1994, sah. 94 ved. 
layarak, bazen uluslararası (andlaşmalar) hukuku iç hukuka üstïn, bazen de iç hukukun uluslararası hukuka (andlaşmalar hukukuna) üstün olduğunu ifade etmektedirler ${ }^{14}$.

\section{B- Türk Iç Hukuku Bakımından}

1982 Anayasamızın 90. maddesi "D. Milletlerarası Antlaşmalan Uygun Bulma" kenarbaşlığı altında I. fikrasında aynen;

"Türkiye Cumhuriyeti adina yabanci devletlerle ve milletlerarast kuruluslarla yapilacak andlaşmalartn onaylanmast, Türkiye Bïyïk Millet Meclisinin onaylamayl bir kanunla uygun bulmasına bağlıdır" ve V. fukrası da yine aynen,

"Usulüne göre yürürlüğe konulmus milletlerarası andlaşmalar kanun hükmïndedir. Anayasaya aykurllk iddiast ile Anayasa Mahkemesine başvurulamaz". hükümlerini içermektedirler.

Çocuk Haklarına Dair Sözleşme, 17, 29, 30. maddelerine ihtirazî kayıt (reservation) konularak zamanın Cumhurbaşkanı Turgut Özal tarafindan 14.9.1990 tarihinde imza edilip, 9.12.1994 t. ve 4058 Nr.1ı Kanunla Türkiye Büyük Millet Meclisince, usulüne uygun bir biçimde onaylanmış ve 244 Nrlı. K. 3. maddesinin 1. bendine göre de, 23.12.1994 t. ve 94/6423 sayılı kararla Bakanlar Kurulunca uygulamaya konulmuş olduğuna göre, Çocuk Haklanna Dair Sözleşme'nin Türk İç Hukuku uygulamalarında meydana gelmesi muhtemel durumlann dikkate alınarak incelenmesi gerekir:

1. Anayasa Bakamından Çocuk Haklarna Dair Sözleşme Hükïmlerinin Uygulanmast:

17, 29, 30. maddelere konulan çekimserlik dışında, Çocuk Haklarına Dair Sözleşme, 1982 Anayasamıza aykırn bỉ hüküm içeriyorsa, Çocuk Haklarına Dair Sözleşmenin, Anayasanın 90. mad. V. fikrasindaki "Bunlar hakkında Anayasaya aykırllk iddiası ile Anayasa Mahkemesine başvurulamaz" hükmii ve 1961 Anayasamızdaki gibi, 1982 Anayasamizın da "başlangı६"ında yer alan Türkiye Cumhuriyeti nin "Dünya Milletler ailesinin essit haklara sahip

14. Bu DUALtST (=ikicilik) ve MONIST (=bircilik) modeller ve yabancr anayasalarda bu modellerin uygulamalar ve onlara ilişkin aynuntıl tartışmalar için bkz. GÖNENÇ, agt., sah. 94-149. 
şerefli bir ̈̈yesi" olmasını vurgulayan ifadesi nedeniyle Türkiye, uluslararasi topluluklarin hukuk düzenine uymak zorundadır ${ }^{15}$.

Çocuk Haklarına Dair Sözleşmenin (Uluslararası Andlaşmanın) Anayasa bakımından uygulanmasında üç ihtimal ortaya çıkmaktadır:

\section{Birinci Ihtimal}

Çocuk Haklarına Dair Sözleşmenin (uluslararası andlaşmanın) hükümüne aykırı olan Anayasa hükmünün değiştirilmesi gerekir.

Ilkinci Ihtimal

Çocuk Haklarına Dair Sözleşmenin (uluslararası andlaşmanın) hükmüne aykurı olan Anayasa hükmünün değiştirilmesi için, sözleşme (ÇHSöz)'nin 50. maddesindeki usullere başvularak sözleşmenin anayasaya aykırı hükümünüin değiştirilmesi önerisinin Birleşmiş Milletler Genel Sekreterliğine yapılması gerekmektedir.

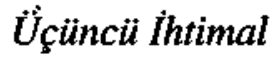

Çekimce (ihtirazî kayıt) koymadan imzaladığı ve Anayasanın 90. maddesine göre onayladığı Çocuk Haklarına Dair Sözleşmenin (Uluslararası andlaşmanın) Anayasaya aykını hükmü varsa ve taraf devletler birinci ve ikinci ihtimallerdeki yollardan birini gerçekleştirmemişse, ÇHSöz. 52. maddesine göre sözleşmenin feshi hakkını kullanabilir. Bu fesih hakkı, yazılı bildirinin Birleşmiş Milletler Genel Sektereliğine ulaştığı tarihten itibaren bir yıl sonra hüküm ve sonuçlar meydana getirir ${ }^{16}$.

Her üç ihtimalde de yani uluslararası andlaşmaya (ÇH.söz.) aykın hüküm içeren Anayasa değiştirilinceye veya sözleşmedeki hükme ilişkin değişiklik teklifi Birleşmis Milletler Genel Kurulunca kabul olunana yahut fesih hakkının kullanılması hüküm ve sonuçlarını getirinceye kadar ulusłararası andlaşmanın (örneğin С̧H:

15. AKIPEK, Ömer tlhan, Devletler Hukuku, I. Kitap, Ankara 1963, sah. 28-30, GÖNENÇ, agt. 133 .

16. Bu ihtimaller CHSöz. esas alınarak dönülmüs olmakla beraber, CHSöz. nin 1982 Anayasamızın hükülmlerine aykıı kurallar bulunmamaktadur. Kaldı ki, 17, 29 ve 30. maddeler için konan çekimce, bu maddeler 1982 Anayasamızla Lozan andlaşmasına aykın olduğu gerekçesiyle konulmuştur. Ayrica bkz, dipnotu 4'deki açıklamalar. 
Söz.nin) Anayasaya aykın kuralları iç hukukta geçerli olarak uygulanacaktır $^{17}$.

2. Çocuk Haklarına Dair Sözleşme Kurallarının Kanunlar Bakimindan Uygulanmast

Burada da değişik ihtimaller üzerinde durarak, değerlendirmeleri yapmak gerekmektedir:

\section{Birinci Ihtimal}

Çocuk Haklanna Dair Sözleşmenin (uluslararası andlaşmanı) imza ve onayından evvel iç hukuk kuralları arasında ÇHSöz'nin (uluslararası andlaşmanın) getirdiği (örneğin, ÇHSöz'nin 15/I. maddesinde düzenlenen çocukların dernek kurma haklarına ilişkin) hükmiü düzenleyen bir kural yoksa, Çocuk Haklarına Dair Sözleşme'nin (uluslararası andlaşmanın) hükmüi iç hukukta uygulama bulur.

\section{Ikinci Ihtimal}

Çocuk Haklarına Dair Sözleşme'nin (ulușlararası andlaşmanın) imza ve onayından evvel iç hukuk kuralları arasında, ÇHSöz. (uluslararası andlaşmanın)'nin düzenlediği husus ilişkin bir kural varsa ve bu kural ÇHSöz (Uluslararası andlaşmanın)'nin hükümlerine aykın ise, ÇHSöz. (uluslararası andlaşmanın)'nin hükmü, iç hukuk kurallarını zımnen (=kapalı olarak) ilga edecek (=yürürlüikten kaldıracak) ve Lex posterior derogat priori (yeni tarihli kural öncelikle uygulanır) ilkesi gereği iç hukuk kuralı gibi uygulanacaktir ${ }^{18}$.

\section{Ü̧üncü Ihtimal}

Çocuk Haklarına Dair Sözleşme (uluslararası andlaşmanın)'nin imza ve onayından sonra, Çocuk Haklarına Dair Sözleşme (uluslararası andlaşmanın)'nin kurallara aykırı (örneğin, ÇHSöz. 1. maddesindeki onsekiz yaşına kadar kişilerin çocuk sayılacağına ilişkin kuralına aykın (örneğin, Medeni Kanunda bir değişiklik yapılarak rüşt yaşı onaltıya indirilmiş yani onaltı yaşına kadar olan kişilerin

17. Karşılaşturıniz GONENC, agt. sah. 148.

18. Anayasa Hukukçulan buna, "Kolaylaş̧ırıımış Anayasa Değişikliği" (Bkz. GONENÇ, agt. sah. 148), buna karşun "Anayasada dízenlenmemiş olan Tenuel Hak ve Özgürlukjler"e ilişkin bir husus, Uluslararası andlaşmalarda düzenlenmisse buna da "Ek Anayasa" adım vermektedirler (Geniş bilgiler için bkz. GöNENÇ, agt. sah. 149). 
çocuk (=küçük) sayılacağı kuralı kanun koyucu tarafindan kabul edilmiş olsa) nitelik taşıyan bir iç hukuk kuralı düzenlemesi yapılmışsa, ÇHSöz. (uluslararası andlaşmaya)'ne aykırı bir kural olmasına değin, bu kural iç hukukta uygulama bulacaktır. Başka anlatımla, aykırı iç hukuk kuralı, ÇHSöz. (uluslararası andlaşma) hükmünü, Lex pesterior derogat priori, ilkesi gereği yürürlükten kaldırmuştır ${ }^{19}$.

\section{Dördüncü Ihtimal}

Yeni tarihli iç hukuk kurall yani ÇHSöz. (uluslararası andlaşmanın''nin yürü̈rlüğe girmesinden sonra konulan iç hukuk kuralı, eski tarihli ÇHSöz. (uluslararası andlaşmanın)'nin kuralına açıkca aykır olmamakla beraber, aykırı olma ihtimali olan bir düzenlemeye sahipse, bu durumda uygulamayı, eski tarihli olan ÇHSöz. (uluslararası andlaşma) hükümlerine göre yeni tarihli iç hukuk kuralını yorumlamak gerekir. Çünkü ÇHSöz. (uluslararası andlaşmayı)'ni imza ve onaylamakla, taraf devletler uluslararası hukuk kuralına (ÇHSöz'ye) uymayı taahhüd etmiş olup, bu taahhüdünï de yerine getirmek zorundadır ${ }^{20}$. Ancak, ÇHSöz. (uluslararası andlaşmaya)'ye açıkça aykın yeni tarihli iç hukuk kuralı getirmişse, taraf devlet artık taahhüdünü geri almak, başka deyişle ÇHSöz. (uluslararası andlaşmayı)'ni fesih etmek niyetinde olduğunu göstermekte$\operatorname{dir}^{21}$.

19. GÖNENC, agt., sah. 148.

20. GÖNENÇ, agt. sah. 148 ved.

21. Bu husustaki yargı uygulamalarına ilişkin Anayasa Mahkemesinin ve Danıstayın Kararları ve eleştirileri hakkında geniş bilgiler için bkz. GÖNENÇ, agt. sah. 49-159 ve oradaki dipnotari $280-285,288-290,292-307$ ve $315,317-319$. 